\title{
Framing the Servitization Transformation Process: A Model to Understand and Facilitate the Servitization Journey
}

\author{
Tim Baines ${ }^{1}$, Ali Ziaee Bigdeli ${ }^{*}$, Rui Sousa ${ }^{2}$, and Andreas Schroeder ${ }^{1}$ \\ ${ }^{1}$ The Advanced Services Group, Aston Business School, Aston University, Birmingham, B4 7ET, UK. \\ ${ }^{2}$ Catolica Porto Business School, Catholic University of Portugal (Porto)
}

\begin{abstract}
The concept of servitization is well established in the literature, and yet the processes of organisational change that manufacturers undergo to compete through services have received much less attention. Therefore, this paper develops a model that enables a description of the servitization processes, the principal stages of organisational change, and the forces impacting these processes. It is based on a series of 14 case studies of the process of servitization over time in multinational manufacturers. Evidence and analysis from these cases are used to establish that manufacturers undergo four stages of organisational maturity (Exploration, Engagement, Expansion and Exploitation), through which an organisation progresses according to the pressures of five principal forces (customer pull, technology push, value network positioning, organisational readiness, and organisational commitment). This progression can be characterised as a business growth model with multiple crises or tipping points. This research contributes to our understanding of the process of servitization and proposes a model which can be used to explain progression. It also forms the basis to better prepare manufacturers as to what to expect as they embark on a servitization journey.
\end{abstract}

Keywords - Servitization, Advanced Services, Process, Transition, Transformation, Organisational Change

Ackknoledgement - This work was supported by Economic and Social Research Council (ESRC) Grant Ref ES/P010148/1: Pathways towards Servitization: A trans-national study of Organisational Transformation, and EPSRC Grants Ref EP/K014064/1, EP/K014072/1, EP/K014080/1: 'Transforming the adoption of Product-Service Systems through innovations in applied gaming technology'. 


\section{INTRODUCTION}

Servitization continues to be a topic of growing importance and interest to both the research and practice communities. For both, an overriding challenge is to understand and manage the transformation processes that manufacturing companies must undergo to compete through services rather than through products alone (Kowalkowski et al., 2017b, Baines et al., 2017). These transformation processes may be wide ranging and complex, often requiring significant organisational change involving operating processes, capabilities, and platforms (Martinez et al., 2017). Yet, despite numerous successful examples such as Goodyear's Proactive Solutions, MAN Truck \& Buses Drivers' Behaviour Monitoring, and Volvo Construction's Proactive Monitoring and Maintenance, many firms struggle to successfully servitize (Lütjen et al., 2017). This study, therefore, examines the processes by which manufacturers transform to compete through services, giving special attention to the more advanced services. It seeks to understand and characterise how a manufacturing organisation changes and matures in introducing, designing, and delivering services.

Much of the preceding servitization research has examined the content, and to some extent its relationship with the context (see Pettigrew, 1988), of organisational change within manufacturing firms, in other words, what have manufacturers changed and what were the circumstances when these changes occurred? (Baines et al., 2017). Much less attention has been given to the process of organisational change through servitization and how this is impacted by the context; in other words: how did (or should) change occur and what the circumstances were (or should be) when change occurs. The absence of research in this area has been noted by Martinez et al. (2017), Lütjen et al. (2017), and Kowalkowski et al. (2017b). All highlight the limitations in our knowledge of the change process arguing that, despite the prevalence of services amongst manufacturing firms, many struggle to understand and manage the transition from product-centric to services-centric businesses. Knowledge about the interplay of environmental factors is also lacking (Baines and Shi, 2015, Brax and Visintin, 2017). Indeed, Finne et al. (2013) draw attention to the need to study how contextual factors affect the change process, and that transition can be slow and cautious because of such factors.

Researchers are now responding to this opportunity. In particular, Martinez et al. (2017) have studied three diverse organisations and argue that the change process is best explained by the theory of continuous change; while Lütjen et al. (2017) interviewed senior managers across 14 firms in the energy sector to suggest that innovation theory describes the servitization process. 
Overall, these researchers agree that the change process is complex and loosely structured, that there is still much to learn, and that fulfilling this need is best achieved through a broad, in-depth and longitudinal study of a range of manufacturers (Vendrell-Herrero et al., 2014).

The study described in this paper, therefore, explores the organisational change process brought about by servitization and how this is impacted by business contextual factors. As explained in the paper, this is based on multiple case studies across 14 multinational manufacturing firms engaging with servitization, with aspirations to compete through advanced services. Data is captured from a range of expert witnesses from all levels within these organisations. These case studies and their analyses have been guided by three research questions which examine: (i) the rationalisation of this process into stages or steps, (ii) the interplay of contextual factors, and (iii) the characteristics of the change process and the theory describing this process. Our analysis leads to three key findings and contributions to servitization research and practice.

First, that at an aggregated level, the process of organisational change through servitization can be explained as four macro-stages: Exploration, Engagement, Expansion and Exploitation. Second, that progression both between and within these macro-stages is significantly influenced by contextual factors, which can be grouped into five categories relating to the customer, technology, the value network, organisational readiness, and the commitment of the host business. Third, that while progression from one macro-stage to the next does appear as structured and predominantly unidirectional, within these are sub-processes which are characteristically organic, unstructured and iterative, and so the whole process can be characterised as a business growth model with multiple crises or tipping points. These three insights are drawn together to form a model (the servitization progression model) that represents how the process of organisational change unfolds as a manufacturer undertakes a servitization journey.

Overall, this study moves forward our understanding of the process of servitization. In particular, it builds on the studies by Martinez et al. (2017) and Lütjen et al. (2017) by understanding how relevant contextual factors affect the servitization process, and reconciling how servitization can be explained theoretically. In addition, it brings together the notions that (i) servitization is a unidirectional and linear shift from products to product-service offerings (Turunen and Finne, 2014), with (ii) the servitization process being neither logical nor structured (Martinez et al., 2017). This study establishes that both characteristics (i.e. unidirectional and unstructured) may be exhibited in practice by a business, depending on the level of aggregation at which the change processes are viewed (i.e. at a macro-level the servitization process may appear to progress linearly, yet the underpinning sub-processes are likely to be unstructured and iterative). From a 
practical perspective, this understanding better prepares managers to appreciate the likely characteristics of a servitization programme and how this will unfold in practice.

The paper is organised, first, to establish and then present the initial research questions. Then, the case study methodology is described, along with the process for data collection and analysis. Analysis and discussion then follow to develop the propositions and the transformation model. The final section provides the conclusion, outlining limitations and setting out an agenda for future research.

\section{THEORETICAL BACKGROUND}

This section sets out the definitions and scope, and develops the research questions for this study as illustrated in Figure 1.

\subsection{Research context and scope}

The origins of servitization research lie with Vandermerwe and Rada (1988) and over the last 30 years servitization has received ever increasing attention by the research community (Baines et al., 2017). Today there is global awareness of the importance of services to manufacturers and yet some important aspects of the processes of servitization are still to be fully explored. This study sets out to contribute to this domain, and so this section summarises the context and scope taken for this work. In particular it provides a foundational (i) definition of servitization, (ii) positioning of servitization against deservitization, (iii) expressing servitization as a transformation process, and (iv) transformation as a process of organisational change. Exploring of these topics are taken in turn.

Servitization is commonly taken to be a transition or transformation which is largely characterised as a linear and gradual move along a product continuum from less to more sophisticated services (Lutjen et al., 2017, and Oliva and Kallenberg, 2003). Such conceptualisation implies a direct relationship between service offerings and the extent of servitization. This is an established view (see Mont (2004), Tukker (2004), Martinez et al. (2010) and Gaiardelli et al. (2014)), and is similar to the notion that a firm's service transformation can be assessed by the number of its service offerings (see Mathieu (2001), Raddats and Burton (2011), Ulaga and Reinartz (2011)). Other researchers, however, see such relationships between service offerings and the extent of servitization as more blurred (see Raddats and Kowalkowski (2014), Windahl and Lakemond (2010)) and that a manufacturer may have a latent capability to offer services, though the commercial environment may limit their saleability and success. These reservations are largely 
addressed by taking servitization to be the innovation of an organisation's capabilities and processes, and that, generally, the extent of servitization can be assessed in terms of the sophistication of services offered (Baines et al., 2009).

Service sophistication varies on the level of risk, competition, and potential to create competitive advantages (Oliva and Kallenberg, 2003, and Eggert et al., 2014). Services can be categorised as either base services (warranties and spare parts), intermediate services (maintenance, repair, overhaul) and advanced services (Baines and Lightfoot, 2013). Advanced services are complex value propositions whereby the manufacturer focuses on providing performance outcomes to customers, and can be thought of as substituting services (Cusumano et al., 2015) that replace the purchase of the product (Paiola et al., 2013). Iconic examples of these include MAN's Pay-perKilometre (Bustinza et al., 2015), which offers comprehensive services around drivers' behaviour and fuel efficiency based on the distance the company's trucks are driven. Such services are also known as Pay-per-Use contracts (Martinez et al., 2017), Outcome-based Contracts (Kowalkowski et al., 2009, Batista et al., 2017), Performance-based Contracts (Kindström and Kowalkowski, 2014) and Capability Contracts (Gebauer et al., 2011). Advanced services are, therefore, a convenient categorisation of more sophisticated services, and have been chosen as the focus for this study.

This study deals with the servitization of the manufacturing firm. A common perception is that servitization is confined to manufacturing, though this is not necessarily the case (Kawalowski et al., 2017, Vandermerwe and Rada, 1988), and service sector companies can also servitize by increasing the bundling of their service offerings. This distinction here is important as the servitization process may differ based on the form of the host organisation. In a similar vein, it is important to recognise that manufacturing firms may go in the opposite direction and move away from service provision. This is the process of deservitization and occurs when a firm reduces or curtails service provision; indeed the interplay between servitization and deservitization is not yet well understood and deserves closer examination (Valtakoski, 2017, Kowalkowski et al., 2017a). However, in this study we have restricted our scope to manufacturing firms engaging with servitization and excluded services businesses or those undergoing deservitization in our research design.

Servitization can, therefore, be taken as the transition or transformation towards advanced services (Lutjen et al., 2017, and Oliva and Kallenberg, 2003). Yet, this opens questions as to whether it is most appropriate to describe the process of servitization as 'transitional' (Oliva and Kallenberg, 2003) or 'transformational' (Vendrell-Herrero et al., 2014). Although the term transition is 
perhaps most dominant in the literature, these terms are frequently interchanged and often taken to mean the same. Yet, there are two types of assumptions in the prevalent literature: either companies move away from products into services, or companies extend or expand their coverage (Finne et al., 2013). The term transition does suggest more of a shift from one state to a second 'Goods to Services', while transformation allows for an extension, where the second state embraces the first 'Goods and Services'. In this sense, IBM demonstrated a transition in moving from producing products to supplying services, whereas Rolls-Royce demonstrated a transformation by expansion of its product portfolio to include services. In this study, we embrace both transformation and transition. However, throughout the paper, we will favour the term transformation, both for brevity in the text and because it suggests a more inclusive approach to servitization.

Given that our chosen definition of servitization focuses on manufacturing organisations, and the innovation of these organisations to offer advanced services, then in this context, transformation is concerned with the processes of organisational change. Organisational change occurs as an interplay between the context, process and content (Pettigrew, 1988, Whipp et al., 1989, Pye and Pettigrew, 2005). Context deals with the circumstances of change (internal and external to organisations), while process deals with how change takes place, and content deals with the actual decisions reached. According to Baines et al. (2017), there is now a relatively well-established body of content-focused research on servitization (e.g., co-design processes (Durugbo, 2014), customer-supplier relationships (Kohtamäki et al., 2013a, Selviaridis and Norrman, 2014), buying processes (Lindberg and Nordin, 2008), network structures/configurations (Ziaee Bigdeli et al., 2018, Kohtamäki et al., 2013b, Nordin et al., 2013, Chakkol et al., 2014, Bikfalvi et al., 2013), and complex networks (Finne et al., 2015). By contrast far less attention has been given to the process aspects of organisational change associated with servitization (Martinez et al., 2017, Brax and Visintin 2017, Kowalkowski et al. 2017b) and, in particular, how this interplays with contextual factors (Baines et al., 2017, Dmitrijeva et al., 2018). Exploring this topic in-depth is, therefore, the focus of this study. 


\section{RESEARCH CONTEXT}

- Servitization of the manufacturing firm

- Servitization as an innovation of an organisation's capabilities and processes

- Transforming or transitioning to deliver advanced services

- Transformation as a process of organisational change

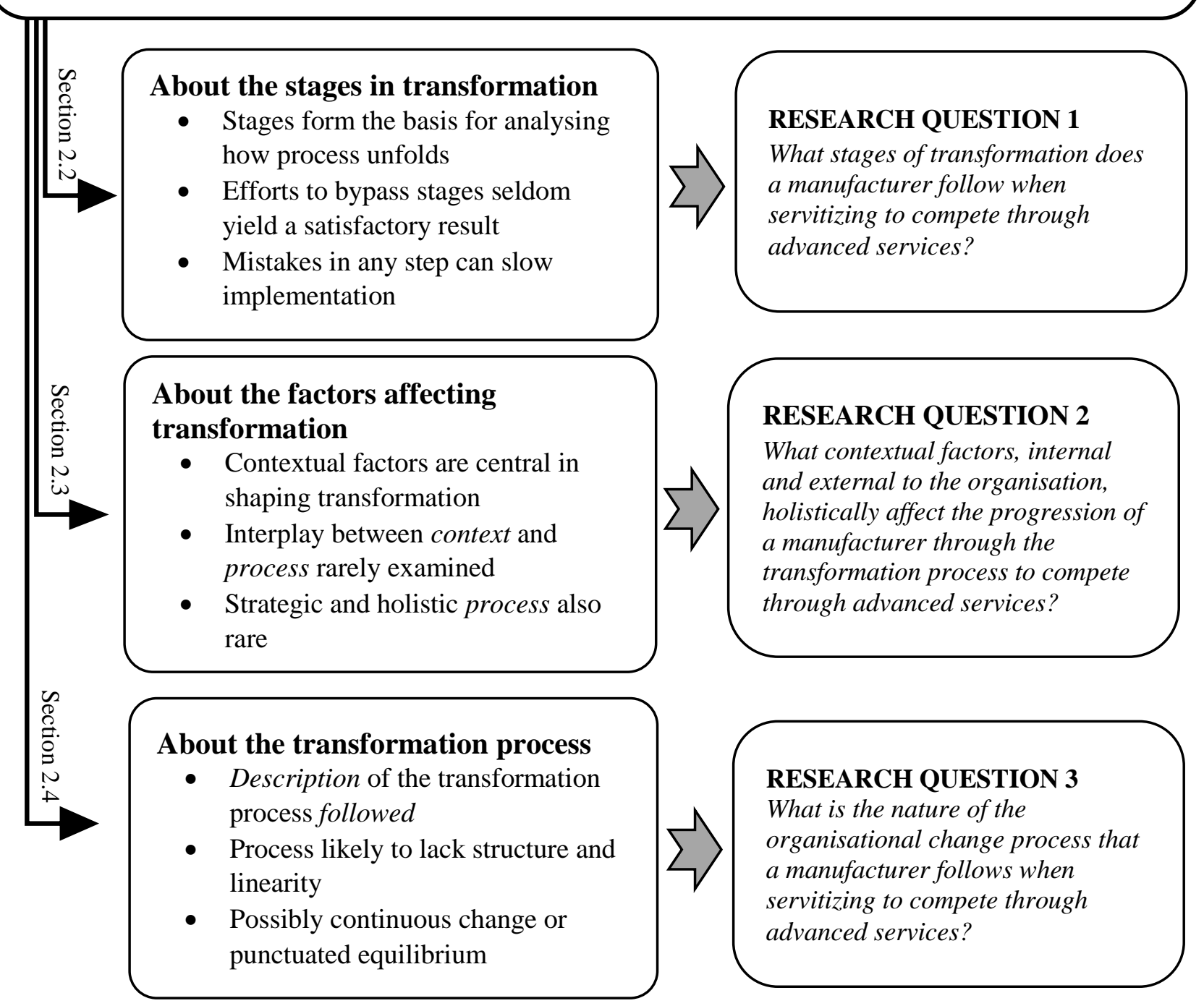

Figure 1. Summary of the theoretical framing of this study

\subsection{About the stages in transformation}

Studies about process differ as to whether they focus on 'describing' the transformation process that manufacturers have followed or 'prescribing' how to go about servitization and change management (see Judson (1991), Kotter (1995), Galpin (1996), Armenakis and Bedeian (1999), and Armenakis et al. (2000)). The former suggests a reflective study and capturing a description 
of the decisions and actions of a manufacturer as the servitization journey unfolds; while the latter is concerned with prescribing a set of analyses and actions that can be followed to guide servitization. Practitioners are especially interested in this latter case, and yet for such prescriptions to be reliable, they should be founded on a thorough understanding and evidence of the former. In this regard, therefore, this study focuses on capturing the transformation that manufacturers have followed (i.e. descriptive).

There is only limited reporting of the step-by-step service journeys of individual firms (VendrellHerrero et al., 2014). Martinez et al. (2017) argue that service-driven transformation requires the reconfiguration of fundamental elements of the product-service offering, organisation and value network, and that such change processes may unfold over a number of phases of emergence, development, implementation and diffusion (Hargrave and Van de Ven, 2006). In their review of servitization literature, Brax and Visintin (2017) discuss stepwise progression models that identify progressive stages of increasing servitization. They note that stepwise models are particularly important, as these indicate stages and form the basis for analysing how the servitization process unfolds, although they also caution against an assumption of the servitization process as unidirectional. On this basis, Lütjen et al. (2017) suggest that early stages tend to be based on already existing products, resources and technologies (Oliva and Kallenberg, 2003), while later stages require substantial changes in the underlying technologies and competences, and in the customer value and behaviours in a greater extent.

Stages or steps are common in prescriptive models, and one of the best-known change management models is that of Kotter and Cohen (2002). Their model consists of eight steps to be followed when implementing fundamental changes: (i) establishing a sense of urgency; (ii) forming a powerful coalition of individuals; (iii) creating a vision and strategy; (iv) communicating the vision; (v) empowering others to act; (vi) creating short-term wins; (vii) consolidating improvements; and (viii) anchoring the new approaches. Such work has its roots in the primary model proposed by Lewin (1947), which consists of unfreezing, moving, and freezing phases. Building on this, Judson (1991), Kotter (1995), Galpin (1996), Armenakis and Bedeian (1999), Armenakis et al. (2000), and Kotter and Cohen (2002) have all proposed multi-staged models to be followed in implementing changes as an organisation's commitment and progress develops. In particular, they extend the Kotter (1995) model to include: (i) readiness for change, and (ii) dealing with resistance when executing a change management programme.

Stages are also common in models describing organisational change. Scott and Bruce (1987) develop a model of organisational transformation and growth, which is based on the classical 
product life-cycle stages. These are (i) inception (which focuses on the idea development), (ii) survival and growth (which focuses on gaining backing), (iii) expansion (which focuses on organisational structures), and (iv) maturity (which focuses on stability). However, both descriptive and prescriptive models emphasise two key points: (i) the change process typically occurs in multiple steps that take a considerable amount of time to unfold, and efforts to bypass steps seldom yield a satisfactory result, and (ii) mistakes in any step can slow implementation as well as negate hard-won progress. These insights lead to our first question about the change process.

$R Q$ 1: What stages of transformation does a manufacturer follow when servitizing to compete through advanced services?

\subsection{About the factors affecting transformation}

Finne et al. (2013) demonstrate that contextual factors are central in shaping the organisational transformation towards servitization. In general, contextual factors are seen as wide-ranging and can be both internal and external to the organisation (Kelly and Amburgey (1991), Pye and Pettigrew (2005), Hatch (2012)). Internal factors include: (i) organisational structure, (ii) corporate culture, (iii) power and leadership, (iv) internal political characteristics, (v) strategic directions, (vi) level of trust and stage of the board development. Whereas external factors include: (vii) external political characteristics, (viii) economics, (ix) social aspects, (x) technology, (xi) environment, (xii) industry, and (xiii) regulations. Several servitization studies have explored some of these factors, such as Gebauer (2008), who has studied how market growth impacts favourable service strategies, and Turunen and Finne (2014), who have examined how servitization success might be affected by technologies and political conditions. Table 1 captures the wide range of such studies that currently exist and illustrates whether they deal with factors that are internal or external to the manufacturer, and the relationship to the content or process of organisational change.

Table 1 illustrates that, predominantly, studies focus on relationships between context (internal \& external) and content. For instance, Ahamed et al. (2013) examine how the internal processes of goal-setting mediated staff concerns during servitization. By contrast, only a few studies consider the relationships between context and process. Those that have can be subdivided into two broad groups: the first dealing with the more strategic and holistic aspects of organisational change, and the second focusing on operational and tactical levels. The former is characterised by 
Kowalkowski et al. (2017a), who examine how agile leadership within a manufacturer impacts the service growth route. An example of the latter is Eloranta and Turunen (2016), who provide a rationale for using platform approaches in the manufacturing context and demonstrate how complex inter-organisational relationships impact value creation processes in service networks.

The paucity of research examining the interplay between context, both internal and external to the organisation, and the strategic and holistic process of servitization transformation, leads us to our second research question.

$R Q$ 2: What contextual factors, internal and external to the organisation, holistically affect the progression of a manufacturer through the transformation process to compete through advanced services?

\begin{tabular}{|c|c|c|c|c|c|}
\hline \multirow[b]{2}{*}{ Authors } & \multirow[b]{2}{*}{ Factor(s) under investigation } & \multicolumn{2}{|c|}{ Context } & \multirow[b]{2}{*}{ 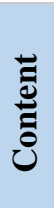 } & \multirow[b]{2}{*}{$\underset{巳}{0}$} \\
\hline & & 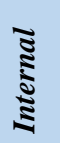 & 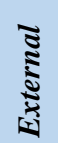 & & \\
\hline (Alghisi and Saccani, 2015) & $\begin{array}{l}\text { Service design capabilities for successful } \\
\text { implementation of service transition strategy. }\end{array}$ & $\star$ & & $\star$ & \\
\hline (Alghisi and Saccani, 2015) & $\begin{array}{l}\text { Top management commitments on investment in } \\
\text { service growth. }\end{array}$ & $\star$ & & $\star$ & \\
\hline $\begin{array}{l}\text { (Kowalkowski et al., } \\
\text { 2017a) }\end{array}$ & Agile leadership on service growth routes. & $\star$ & & & $\star$ \\
\hline $\begin{array}{l}\text { (Alghisi and Saccani, 2015, } \\
\text { Lienert, 2015, Martinez et } \\
\text { al., 2010, Johnstone et al., } \\
\text { 2009, Gebauer and Friedli, } \\
\text { 2005) }\end{array}$ & $\begin{array}{l}\text { Internal marketing to create the internal buy-in } \\
\text { that establishes the service culture. }\end{array}$ & $\star$ & & $\star$ & \\
\hline (Burton et al., 2017) & $\begin{array}{l}\text { New responsibilities/organisational realignment } \\
\text { for service delivery. }\end{array}$ & $\star$ & & $\star$ & \\
\hline (Parida et al., 2014) & $\begin{array}{l}\text { Network management capabilities to facilitate the } \\
\text { servitization transformation. }\end{array}$ & $\star$ & & & $\star$ \\
\hline (Ulaga and Reinartz, 2011) & $\begin{array}{l}\text { Availability of resources and knowledge on new } \\
\text { service development. }\end{array}$ & $\star$ & & $\star$ & \\
\hline (Gebauer and Friedli, 2005) & $\begin{array}{l}\text { Employee education to facilitate the piloting of } \\
\text { the service offering. }\end{array}$ & $\star$ & & $\star$ & \\
\hline (Ahamed et al., 2013) & $\begin{array}{l}\text { Clear goal-setting and performance criteria } \\
\text { development to streamline internal processes for } \\
\text { service development. }\end{array}$ & $\star$ & & $\star$ & \\
\hline
\end{tabular}




\begin{tabular}{|c|c|c|c|c|c|}
\hline (Bastl et al., 2012) & $\begin{array}{l}\text { Shifts towards user process-oriented services on } \\
\text { the creation of a push for more collaborative } \\
\text { relationships. }\end{array}$ & & $\star$ & $\star$ & \\
\hline (Turunen and Finne, 2014) & $\begin{array}{l}\text { Regulatory changes that can ban or facilitate new } \\
\text { product-service offerings. }\end{array}$ & & $\star$ & $\star$ & \\
\hline (Benedettini et al., 2015) & $\begin{array}{l}\text { Broader social values, the customers' satisfaction, } \\
\text { relationship, loyalty and retention with the } \\
\text { organisation, which can facilitate servitization. }\end{array}$ & & $\star$ & $\star$ & \\
\hline (Neely, 2008) & $\begin{array}{l}\text { The level of economic development, which can } \\
\text { impact servitization. }\end{array}$ & & $\star$ & $\star$ & \\
\hline $\begin{array}{l}\text { (Story et al., 2017, Baines } \\
\text { and Lightfoot, 2014, } \\
\text { Lightfoot et al., 2011) }\end{array}$ & $\begin{array}{l}\text { ICT that facilitates servitization by improving the } \\
\text { delivery of new services. }\end{array}$ & $\star$ & & $\star$ & \\
\hline $\begin{array}{l}\text { (Holmström and Partanen, } \\
\text { 2014) }\end{array}$ & $\begin{array}{l}\text { Technology-driven design of solutions which } \\
\text { facilitates servitization by allowing for new } \\
\text { offerings to be considered. }\end{array}$ & $\star$ & & $\star$ & \\
\hline (Bustinza et al., 2013) & $\begin{array}{l}\text { The capability to collect data on the customers' } \\
\text { experience of goods/services to allow for a better } \\
\text { insight into service-related consumer behaviour. }\end{array}$ & $\star$ & & $\star$ & \\
\hline $\begin{array}{l}\text { (Opresnik and Taisch, } \\
\text { 2015, Lee et al., 2014) }\end{array}$ & $\begin{array}{l}\text { Visualisation and analysis techniques for the } \\
\text { processing of big data to facilitate the } \\
\text { establishment of new service propositions. }\end{array}$ & $\star$ & & $\star$ & \\
\hline (Wilkinson et al., 2009) & $\begin{array}{l}\text { Supply chain integration on the development of } \\
\text { new service offering. }\end{array}$ & & $\star$ & $\star$ & \\
\hline $\begin{array}{l}\text { (Kamp and Parry, 2017, } \\
\text { Story et al., 2017) }\end{array}$ & $\begin{array}{l}\text { The open sharing of data and knowledge which } \\
\text { can enable collaborative working between buyers } \\
\text { and suppliers and the joint development of new } \\
\text { service offerings. }\end{array}$ & & $\star$ & $\star$ & \\
\hline $\begin{array}{l}\text { (Eloranta and Turunen, } \\
\text { 2016) }\end{array}$ & $\begin{array}{l}\text { Platform approaches to provide structure for } \\
\text { managing network cooperation in the servitization } \\
\text { process. }\end{array}$ & & $\star$ & & $\star$ \\
\hline (Story et al., 2017) & $\begin{array}{l}\text { Managing partner relationships in the network to } \\
\text { support the service value co-creation within the } \\
\text { network. }\end{array}$ & & $\star$ & $\star$ & \\
\hline
\end{tabular}

Table 1. Servitization studies' focus on relationships between context and content

\subsection{About the transformation process}

Servitization is often seen as a unidirectional and linear shift from products to product-service offerings and, yet, practice rarely plays out so objectively (Spring and Araujo, 2013). Indeed, on the basis of three in-depth cases studies, Martinez et al. (2017) conclude that the servitization process is neither logical nor structured, but is much more emergent and intuitive. Spring and Araujo (2013) stress the continuously emergent and exploratory nature of the shift to service, and conceptualise the restless firm - in conjunction with its restless network counterparts - which is 
engaged in network reconfiguration rather than simply 'moving downstream'. Similarly, Kowalkowski et al. (2012) suggest that the transition takes place through 'agile incrementalism' as opportunities are seized and improvements take place independent of a centralised servitization strategy. Wilkinson et al., (2009) recognise systemic characteristics and, rather than sequential steps, they suggest that transition takes place through the resolution of organisational problems along the way.

These differing views of transformation are reflected in the broader literature on organisational change, which is dominated by two approaches: (i) continuous change and (ii) punctuated equilibrium. The continuous change approach emphases a situation where organisations and their people continually monitor, sense, and respond to the external and internal environment in small steps as an ongoing process (Luecke, 2003). Burnes (2004) identifies continuous change as the ability to change continuously in a fundamental manner. The theory of continuous change suggests that change is not episodic but endemic to the way in which organisations operate, having the ability to engage in rapid and relentless continuous change (Langley et al., 2013). By contrast, punctuated equilibrium is characterised by long periods of relative peacefulness with small, incremental changes that are interrupted by brief periods of discontinuous and radical change (Tushman and Anderson, 1986). There are other frameworks that also explain this organisational change process. In particular, Scott and Bruce (1987) propose a model of business growth that somewhat reconciles the differences between linear growth and radical change. They identify five stages which are punctuated by four crisis points that precede the advance into the next stage of development. It is the anticipation of these crises, and the successful management of the change that they cause, that ensures the survival of the growing business.

Servitization research has yet to settle on which model or theory is most appropriate for explaining the transformation process. The relatively exploratory work by Martinez et al. (2017) argues that the change process is best explained by the theory of continuous change; though Lütjen et al. (2017), having interviewed senior managers across 14 firms in the energy sector, suggest that the innovation management perspective also explains the organisational change process. This leads us to conclude that further work is necessary in this area and leads to our final research question.

$R Q$ 3: What is the nature of the organisational change process that a manufacturer follows when servitizing to compete through advanced services? 


\section{RESEARCH METHOD}

This study set out to illuminate the transformation process that a product-centric manufacturer undertakes as it servitizes to compete through advanced services. Given the nature of the research questions, this paper has adopted a multiple case study approach that allows the examination of replication logic (Yin, 2003), a condition in which empirical analyses can be seen as a series of independent experiments that confirm or disconfirm conceptual insights as they emerge (Eisenhardt, 1989). This section describes the case selection as well as the data collection and analysis methods.

\subsection{Case selection}

A critical aspect of the study was securing the participation of manufacturers involved in servitization, and specifically involved with a transformation centred on competing through advanced services. However, identifying such a pool is fraught with challenges. The research team faced two issues in particular: (i) an ideal case company would have fully executed and experienced a transformation process, yet the anticipated extended time-line of such a process (i.e. several years) means that evidence of earlier stages of maturity are unlikely to be available within such organisations; and (ii) an ideal case company would report business performance indicators about advanced services, yet financial conventions for such reporting differ across businesses (Baines and Lightfoot, 2013). The solution for this study was to accept a less specific selection and, instead, allow manufacturers to be chosen as case candidates if they indicated some reliable evidence of a trajectory towards advanced services. For example, early experimentation with an outcome-based contract or developing a services-led offering were considered to be positive indicators. As a result, selected cases were at different levels of organisational readiness in the development and delivery of advanced services, and evidence of this was recorded and analysed for scrutiny (see Section 4.1).

Search, selection and engagement proceeded as follows. A range of techniques was used to establish a shortlist of companies, including: (i) monitoring attendees at field service networking events, (ii) participating in forums and networking on LinkedIn, (iii) reviewing articles in professional periodicals and magazines, and (iv) web searches for businesses that have associations with advanced service-type contracts. During the process, extra care was taken to: (i) focus on manufacturers (note that services business can also offer forms of advanced services), (ii) achieve a broad view of transformation by covering a range of servitization maturity levels, 
and (iii) avoid selection of competing companies since this would inhibit willingness to participate.

Shortlisted companies were then invited to participate in this study. The participating companies had to agree to: (i) provide access to middle/senior management, (ii) take part in several rounds of interviews, workshops, meetings, etc., and (iii) grant the research team access to their facilities to observe day-to-day operations. Following this process, 14 company cases were identified and preliminarily engaged by August 2014. For all cases, negotiations concerning access and confidentiality were carried out, and, therefore, the names of the manufacturing organisations have been coded (Case A through to Case N). An overview of the selected cases is provided in Table 2. 


\begin{tabular}{|c|c|c|c|}
\hline $\begin{array}{l}\text { Case } \\
\text { Identifier }\end{array}$ & Industry/ Business Focus & $\begin{array}{l}\text { Size (Turnover/No. } \\
\text { of Staff) }\end{array}$ & Evidence of Advanced Services Trajectory (Reason for Engagement in Study) \\
\hline Case A & $\begin{array}{l}\text { Passenger and commercial } \\
\text { vehicle and aircraft tyre } \\
\text { manufacturer }\end{array}$ & $\sim £ 12 \mathrm{bn} / \sim 70,000$ & $\begin{array}{l}\text { Chief Innovation Officer approached research team to enquire about transformation expertise and } \\
\text { to identify industry leaders. }\end{array}$ \\
\hline Case B & Gas turbine engine manufacturer & $\sim £ 8$ bn $/ \sim 50,000$ & Frequently cited in publications as exemplar of advanced services. \\
\hline Case C & Rail transportation manufacturer & $\sim £ 7 \mathrm{bn} / \sim 32,000$ & Cited in trade press as most innovative and successful advanced service provider in rail industry. \\
\hline Case D & Heavy equipment manufacturer & $\sim £ 30 \mathrm{bn} / \sim 95,000$ & Frequently cited as exemplar of advanced services in business and management publications. \\
\hline Case $\mathbf{E}$ & $\begin{array}{l}\text { Manufacturer and provider of } \\
\text { document solutions and services }\end{array}$ & $\sim £ 10 \mathrm{bn} / \sim 36,000$ & $\begin{array}{l}\text { Widely cited in trade press as most pioneering and successful advanced service provider of printing } \\
\text { machinery. }\end{array}$ \\
\hline Case F & Truck and trailer manufacturer & $\sim £ 550 \mathrm{~m} / \sim 34,000$ & CEO engaged research team to audit advanced service operations with customers. \\
\hline Case G & $\begin{array}{l}\text { Packaging equipment } \\
\text { manufacturer }\end{array}$ & $\sim £ 600 \mathrm{~m} / \sim 3,500$ & $\begin{array}{l}\text { Service Director engaged in discussion around advanced services at tradeshow, discussed industry } \\
\text { trends, and how the company sought to innovate their offerings. }\end{array}$ \\
\hline Case $\mathbf{H}$ & $\begin{array}{l}\text { Manufacturer of air filtration } \\
\text { equipment }\end{array}$ & $\sim £ 3 \mathrm{bn} / \sim 1,900$ & $\begin{array}{l}\text { Director of IoT engaged in discussion around advanced services at tradeshow, discussed need to } \\
\text { capture value through advanced services. }\end{array}$ \\
\hline Case I & Heavy equipment manufacturer & $\sim £ 5 \mathrm{bn} / \sim 18,000$ & $\begin{array}{l}\text { Service Director engaged in discussion around advanced services at tradeshow, discussed } \\
\text { aspiration to compete through advanced services. }\end{array}$ \\
\hline Case J & $\begin{array}{l}\text { Manufacturer of precision motion } \\
\text { control systems }\end{array}$ & $\sim £ 2$ bn $/ \sim 10,700$ & $\begin{array}{l}\text { Director of IT approached research team to deliver keynote on advanced services at their annual } \\
\text { service conference. }\end{array}$ \\
\hline Case $\mathbf{K}$ & $\begin{array}{l}\text { Power generation, renewable } \\
\text { energy and transmission } \\
\text { manufacturer }\end{array}$ & $\sim £ 26 \mathrm{bn} / \sim 74,000$ & $\begin{array}{l}\text { Engaged in discussion with business development team following presentation by research team } \\
\text { at field service conference. }\end{array}$ \\
\hline Case $\mathbf{L}$ & $\begin{array}{l}\text { Aerospace and defence } \\
\text { equipment manufacturer }\end{array}$ & $\sim £ 16 \mathrm{bn} / \sim 85,000$ & $\begin{array}{l}\text { The research team was introduced to new Business Development Manager with interest in } \\
\text { advanced services via university liaison officer. }\end{array}$ \\
\hline Case $M$ & $\begin{array}{l}\text { Lifting and material-handling } \\
\text { manufacturer }\end{array}$ & $\sim £ 700 \mathrm{~m} / \sim 3,800$ & $\begin{array}{l}\text { Service Director engaged in discussion around advanced services following his presentation at } \\
\text { field service event. }\end{array}$ \\
\hline Case $\mathbf{N}$ & $\begin{array}{l}\text { Manufacturer of transport } \\
\text { temperature control systems }\end{array}$ & $\sim £ 2 \mathrm{bn} / \sim 10,000$ & $\begin{array}{l}\text { Widely cited as the leading company in developing and delivering advanced services where } \\
\text { controlled temperature is vital. }\end{array}$ \\
\hline
\end{tabular}

Table 2. Overview of the selected case companies 


\subsection{Data collection}

Data collection occurred in the period 2014-2018 and was supported by a data collection protocol based around the research questions. Accordingly, data was collected principally through semistructured interviews (both face to face and by telephone) from a range of personnel levels. Interviews directly reflected the research questions, and were designed to guide the conversation flow towards a characterisation of servitization initiatives over time, focusing on process, as well as the contextual forces affecting progress towards increased servitization maturity. At least two researchers were present at each interview, and responses were captured by both audio recording and written notes. Each interview lasted from one to two hours. Overall, the study conducted 62 rounds of interviews, with at least three key stakeholders from each case company, resulting in more than 100 hours of recorded material. Written transcripts were prepared soon after each interview. Triangulation (Jick, 1979) was carried out to verify responses and included supplementary data, such as observation notes, organisational charts, process maps, operating protocols, and crosschecked responses from interviewees.

In addition, data collection included informal follow-ups through meetings and workshops and several rounds of on-site observations. After each of these activities, the involved researchers produced a written description of the gathered data (e.g. an account of the salient aspects discussed in a meeting). Finally, we examined archival data (mainly business plans, annual reports and internal company materials), extracting relevant information - as per the themes associated with the research questions - and transcribing/summarizing it into text, while keeping a reference to the raw data source. All of these written notes (from interviews and additional data sources) made up the case-study database (Yin, 2003) that was used for subsequent data analysis.

\subsection{Data analysis process}

We followed the principles of qualitative data analysis (Miles and Huberman, 1994) to describe, interpret and categorise the data. The key mechanisms for generating meaning from the data were noting patterns, seeing plausibility, clustering, making contrasts/comparisons, and subsuming particulars into the general (Miles and Huberman, 1994). We first performed within-case analysis, starting by organising the data around each of the research questions. We coded the data against the research questions, while simultaneously allowing for new codes and relationships to emerge inductively from the data. In order to ensure reliability and construct validity, the data was coded by two independent researchers and different interpretations of the data (e.g. classification of codes 
into broader conceptual categories) were discussed vis-à-vis raw data to arrive at a consensual coding. We then performed cross-case analysis by summarising the data from each case and building displays to reveal cross-case patterns and make comparisons. Validity was further enhanced by identifying commonalities across cases, as well as by comparing cases with different levels of progression in servitization over time (Yin, 2003). Finally, we presented our findings (stages and their timing, and key contextual factors affecting progression and reconstructed pathways) to informants in each case to assess plausibility (Yin, 2003).

Analysing the findings to answer the research questions led to the formation of propositions that explain the transformation process. The next section provides additional details on the data analysis and reports the findings for each of the research questions.

\section{ANALYSIS AND FORMATION OF THE TRANSFORMATION MODEL}

\subsection{Principal stages in the transformation process (RQ1)}

From the onset, it was apparent that multiple stages of transformation maturity do exist. Case A, for instance, was concluding their activities centred on the ways in which further value could be created for current and prospective customers, and also searching for industrial exemplars that the company could study in detail. As their Chief Innovation Officer noted: 'We started by exploring the ideas around servitization by investigating the practices of manufacturers in our or other industries, what could we learn from them, and how should we go about it.' Similarly, Cases B and $\mathrm{C}$ were also quite developed in their transformation journey and were focusing on their organisational strategy to optimise the delivery of advanced services, and exploit their servicesled offering portfolios. In contrast, Case I was much less mature and struggling to conceptualise what an advanced service might look like for their industrial products. Indeed, they were questioning whether they might be most successful if they simply sought to sell data captured about their products directly back to their customers without any complementary services. Other cases, such as J, L and M, operated between these extremes: experimenting with offerings around advanced services, having a strong ambition to grow their portfolios, and exploring the potential of such services to their future competitive advantages.

We analysed the data with the goal of representing this progression through the transformation process at an appropriate level of abstraction, seeking to identify meaningful, distinctive stages. The data was coded to identify the significant actions or events associated with the servitization process over time in each case (as per the interviewees' accounts and other sources of data). The codes were then used to build a timeline for each case. To illustrate, Figure 2 shows the timeline 
for Case A. We then iteratively analysed the servitization events within and across cases against the lenses of the different change models discussed in Section 2.4, grouping actions/events according to their conceptual similarity. 


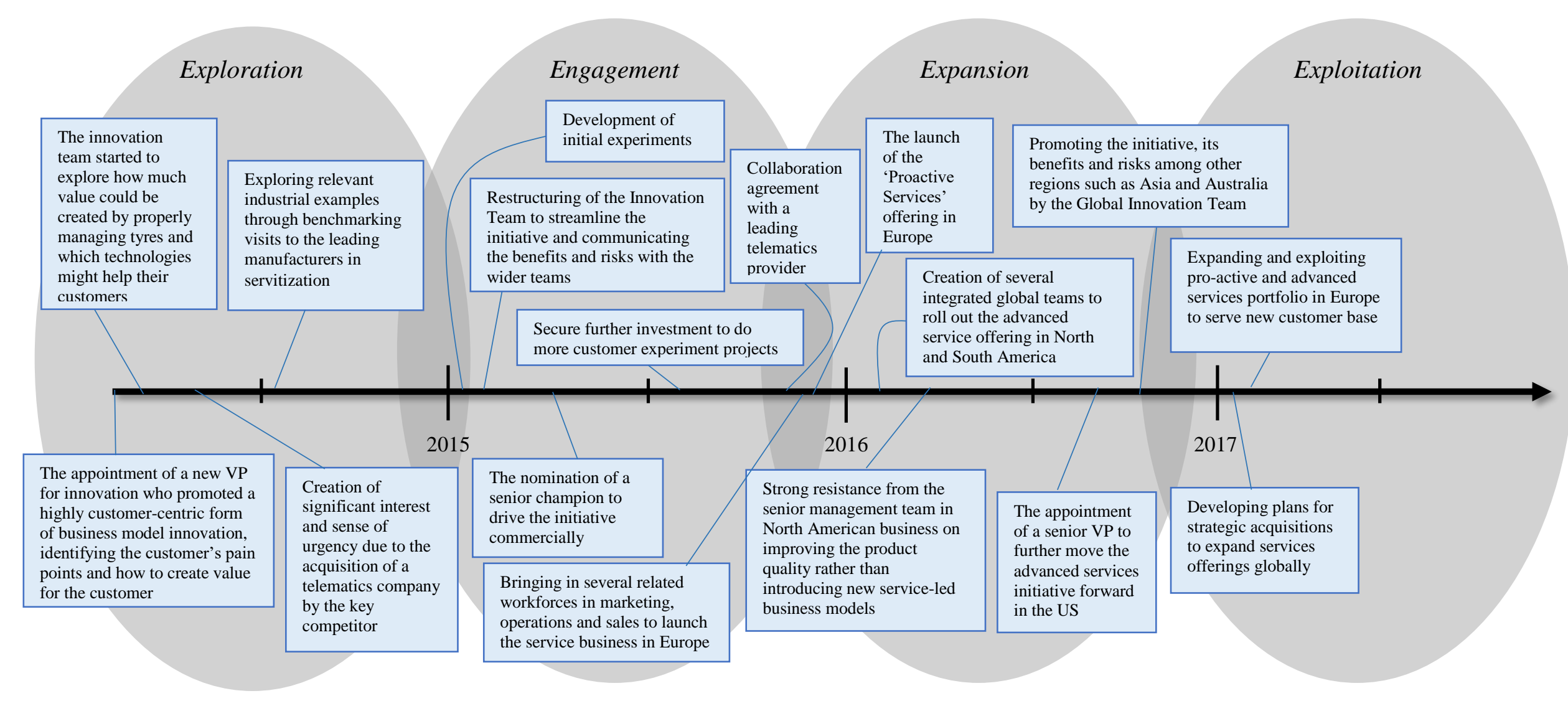

Figure 2. Timeline of the servitization process events and actions for Case A 
Four conceptual categories of events in the transformation process became apparent. We found that, in each case, the events associated with each category clustered around a well-delimited time period, thus constituting different stages of maturity. In addition, each stage exhibited similar features across firms. These stages were well aligned with the four stages described in the model of organisational change proposed by Scott and Bruce (1987). The terminology and definitions of the stages were revised to better represent the servitization and advanced services context: Exploration, Engagement, Expansion, and Exploitation. By looking at the nature of the events grouped under a given stage we produced an abstract description for each stage. Table 3 summarises the features of each stage and provides illustrations from the case studies in the form of managerial concerns that were salient in each stage (from interview data).

\begin{tabular}{|c|c|c|c|c|}
\hline & Exploration & Engagement & Expansion & Exploitation \\
\hline Definition & $\begin{array}{l}\text { Searching and } \\
\text { finding out about the } \\
\text { concept and the } \\
\text { implications of } \\
\text { competing through } \\
\text { advanced services, } \\
\text { until they are } \\
\text { confident that the } \\
\text { opportunity exists. }\end{array}$ & $\begin{array}{l}\text { Seeking to evaluate } \\
\text { and demonstrate } \\
\text { advanced services, } \\
\text { until the potential is } \\
\text { accepted within the } \\
\text { organisation. }\end{array}$ & $\begin{array}{l}\text { Increasing the scale } \\
\text { and speed at which } \\
\text { advanced services are } \\
\text { innovated and } \\
\text { implemented, until } \\
\text { significant value is } \\
\text { demonstrated within } \\
\text { the organisation. }\end{array}$ & $\begin{array}{l}\text { Seeking to optimise } \\
\text { innovation and } \\
\text { delivery of an } \\
\text { advanced services } \\
\text { portfolio, unless } \\
\text { business is adversely } \\
\text { disrupted. }\end{array}$ \\
\hline $\begin{array}{l}\text { Illustrations } \\
\text { from the case } \\
\text { studies } \\
\text { (managerial } \\
\text { concerns) }\end{array}$ & $\begin{array}{l}\text { Is this right for us? } \\
\text { (CEO, Case F) } \\
\text { How much money } \\
\text { could we make? } \\
\text { (Service Director, } \\
\text { Case E) } \\
\text { Who does this well? } \\
\text { (Business } \\
\text { Development } \\
\text { Manager, Case L) } \\
\text { What are the key } \\
\text { customer } \\
\text { requirements? (CIO, } \\
\text { Case A) } \\
\text { What is the overall } \\
\text { organisational mind- } \\
\text { set on services? } \\
\text { (Service Director, } \\
\text { Case J) } \\
\text { What are our } \\
\text { differential }\end{array}$ & $\begin{array}{l}\text { How do I get the } \\
\text { board to invest? } \\
\text { (Technical Director, } \\
\text { Case G) } \\
\text { How do we educate } \\
\text { our customers? } \\
\text { (CEO, Case F) } \\
\text { Why can't we just } \\
\text { sell our monitoring } \\
\text { technology? (Service } \\
\text { Director, Case I) } \\
\text { What is the right } \\
\text { business model? } \\
\text { (CIO, Case A) } \\
\text { What should be } \\
\text { considered as KPIs in } \\
\text { experimentation } \\
\text { projects? (Service } \\
\text { Director, Case G) }\end{array}$ & $\begin{array}{l}\text { How do we overcome } \\
\text { our production } \\
\text { legacy? (Service } \\
\text { Solutions Director, } \\
\text { Case M) } \\
\text { How do we build our } \\
\text { market share? } \\
\text { (Service Director, } \\
\text { Case J) } \\
\text { Who are our } \\
\text { competitors now? } \\
\text { (Service Director, } \\
\text { Case E) } \\
\text { How could this } \\
\text { become an } \\
\text { organisation-wide } \\
\text { initiative? (CIO, Case } \\
\text { A) } \\
\text { What acquisitions } \\
\text { should we make? } \\
\text { (CIO, Case A) }\end{array}$ & $\begin{array}{l}\text { How do we integrate } \\
\text { production with } \\
\text { service? (Senior } \\
\text { Engineering } \\
\text { Manager, Case B) } \\
\text { How do we extend } \\
\text { our services } \\
\text { business? (CFO, } \\
\text { Case F) } \\
\text { What next, both in } \\
\text { terms of the service } \\
\text { portfolio and } \\
\text { organisation } \\
\text { direction? (Service } \\
\text { Director, Case C) } \\
\text { How do we improve } \\
\text { efficiency of service } \\
\text { delivery? (IT } \\
\text { Director, Case H) }\end{array}$ \\
\hline
\end{tabular}


advantages?

(Solutions Manager,

Case L)

Table 3. Characterisation of the four stages of servitization maturity

Table 4 shows for each case the predominant incidence over time of traits associated with the four stages. It reveals that all firms seem to follow the same sequence, though not all companies had managed to progress through each stage at the time of the research. In addition, there is no evidence that firms skipped stages. Overall, the data supports the existence of the four stages in servitization journeys. 


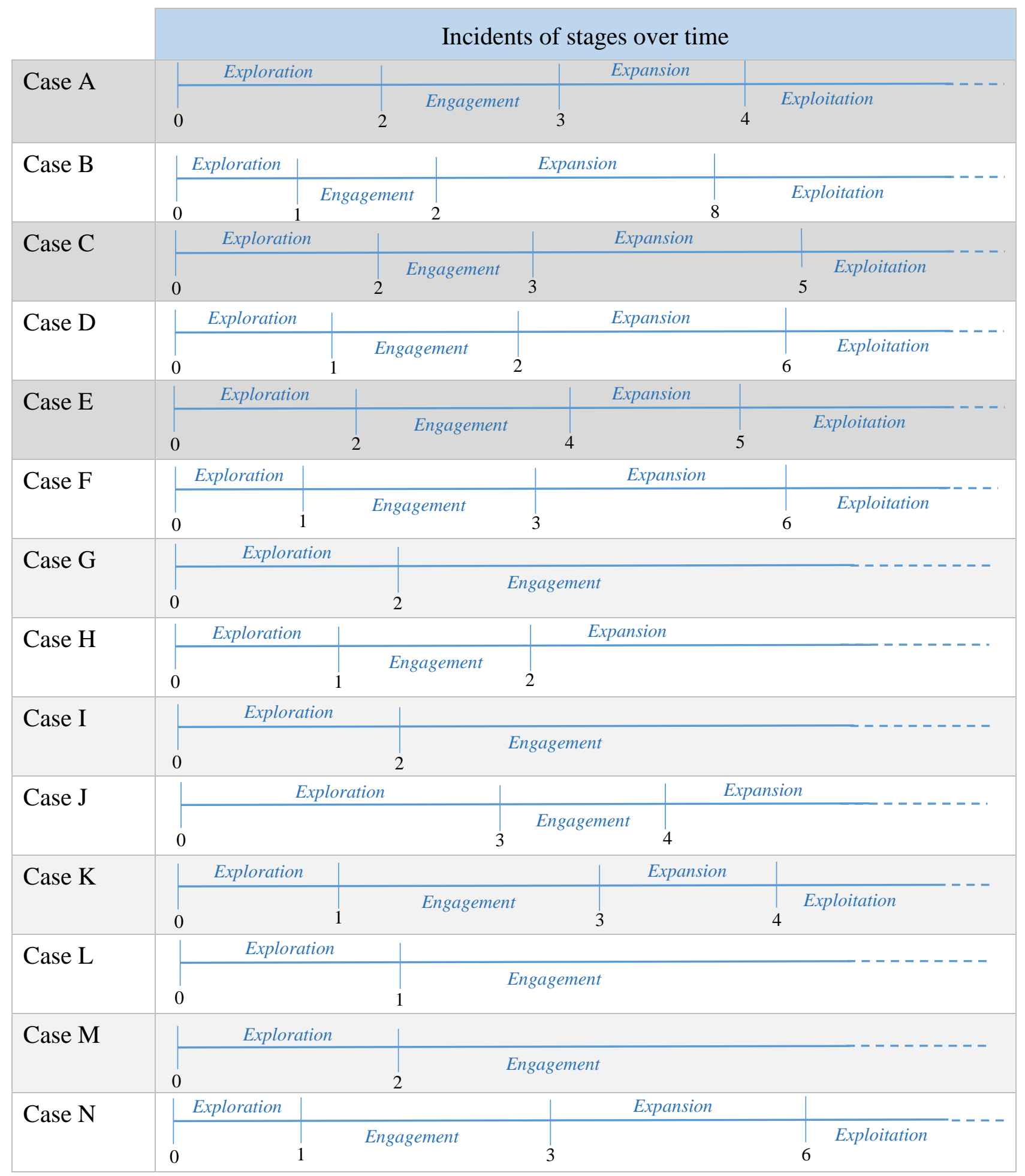

* Note: Time units are in years. 0 signals the start of the journey for the relevant case

Table 4. Cross-case mapping of maturity stages over time 
This conceptualisation of the transformation process as four stages provides a viable structure for differentiating the progress of the case companies. In the first phase of Exploration, all the case companies were looking to understand their market and explore how advanced services could play a key part in their growth. For instance, the CEO of Case F explained: 'We started to explore what are the pain points of our customers - we found that it wasn't the price of the truck at all; it was the cost of fuel as well as uptime ... we started to realise we can do a lot to address those pains.' Similarly, the Business Development Manager of Case K said, 'We started to be aware of the requirements and needs of our customers through a reverse engineer initiative, it feels like "by the way you'll need one of those, and one of those, and one of those. And you stick them together like this".'

In the second stage, Engagement, the focus shifted towards securing internal backing, both financially and organisationally. The CIO in Case A stated:

We started to build alignment with the people inside the organisation for the advanced services initiatives. There was a sponsor for a group of three people who were business leaders ... so partly it was keeping them in the loop, bringing them up to date with what the global team was doing and building relationships with them.

Similarly, the Business Development Manager of Case E said:

After understanding the basics of the market and our offering, we had to think about an internal coalition to take the advanced services initiative forward ... The team was one-hundred-percent dedicated to advanced services initiatives ... in hindsight I look back and I don't think it would have succeeded had it not been a dedicated group. There was never a pressure to support the core business; the pressure was to go and prove the new venture to be successful.

In the Expansion stage, the focus and efforts moved to scaling a portfolio of advanced service offerings, creating a larger market segment and enhancing cultural change initiatives. The CIO of Case A noted:

After the success of several rounds of experimentations with the selected customers (for nearly 18 months), we launched our first advanced services offering. It was initially called [xxx], but later changed to Proactive Services. The offering focused on taking care of the entire tyrerelated operation for the road haulage companies through the sensor-enabled monitoring of tyre pressure and alerts, based on a monthly service fee model. A dedicated team from innovation, marketing and sales came together to work closely in identifying new relevant customers across the continent. 
The General Manager of Case $\mathrm{N}$ also explained:

There's nothing like having a successful project to start to open people's minds ... it became real for people at that point; they could see this project, this customer, these outcomes ... here's the financial performance of that transaction, how it fits into the $P \& L$ of the business.

At the time of data collection, only eight of the case companies had reached the Exploitation stage of transformation, where their efforts started to focus more on institutionalising servitization across different business units and on designing their products with the mind-set required for the delivery of advanced services. On this concern, a Senior Engineering Manager from Case B stated: 'Today, our engines are designed and manufactured in a way that enables us to provide and deliver advanced services more effectively towards our customers.' Similarly, a Senior Business Development Manager from Case N highlighted: 'Rather than having an organisation for building the products and an organisation for supporting the products - which we have currently - we now realise that we will need to manage a product through-life and have an organisational structure to reflect this.'

Therefore, in response to the first research question, we offer:

Proposition 1: In a manufacturer's transformation to servitize and compete through advanced services, the organisation will experience four stages of process maturity as the organisation's commitment and capabilities progress.

Proposition 1.1 The manufacturer will firstly focus on Exploration, searching and finding out about the concept and the implications of competing through advanced services, until it is confident that the opportunity exists.

Proposition 1.2 The manufacturer will secondly focus on Engagement, seeking to evaluate and demonstrate advanced services, until the potential is accepted within the organisation.

Proposition 1.3 The manufacturer will thirdly focus on Expansion, increasing the scale and speed at which advanced services are innovated and implemented, until significant value is demonstrated within the organisation. 
Proposition 1.4 The manufacturer will fourthly focus on Exploitation, seeking to optimise innovation and delivery of an advanced services portfolio, unless business is adversely disrupted.

\subsection{Principal contextual factors that affect progression through the transformation process (RQ2)}

We analysed the data based on first-order and second-order coding (Strauss and Corbin, 1998, Miles and Huberman, 1994). We started by coding the data (mainly interview data) for incidents or phenomena that constituted an evidence (or manifestation) of a contextual factor shaping the transformation process, assigning a first-order code to each. Then we grouped these factors into aggregate second-order conceptual factors. Establishing a second-order factor required the existence of at least two conceptually related first-order incidents associated with different data sources (e.g., two different respondents). For example, appetite from customer base to experiment new innovations, and commitments from key customers to engage in experimentation projects were grouped under customer pull. Since the literature is scarce on contextual factors pertaining to the servitization process (see Section 2.3), this was primarily an inductive process. The process as a whole was iterative, involving the revision of the definitions of the second-order factors to arrive at a comprehensive and consistent set of factors. The analysis resulted in five categories of factors: customer pull, technology push, value network positioning, organisational readiness and organisational commitment. Table 5 shows the result of the cross-case data analysis. 


\begin{tabular}{|c|c|c|c|c|c|c|c|c|c|c|c|c|c|c|c|}
\hline \multirow[b]{2}{*}{ 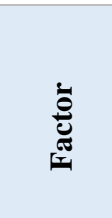 } & \multicolumn{14}{|c|}{ Presence of factors across cases } & \multirow[b]{2}{*}{ Examples from cases } \\
\hline & 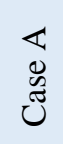 & $\begin{array}{l}n \\
0 \\
\tilde{\Xi} \\
\tilde{w}\end{array}$ & $\begin{array}{l}u \\
0 \\
\tilde{z} \\
\tilde{z}\end{array}$ & ๑ & $\begin{array}{l}\text { II } \\
0 \\
\tilde{U}\end{array}$ & $\begin{array}{l}1 \\
0 \\
\tilde{J} \\
\tilde{J}\end{array}$ & $\begin{array}{l}0 \\
0 \\
\tilde{U} \\
\tilde{U}\end{array}$ & 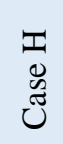 & Uే & $\overrightarrow{0}$ & $\begin{array}{l}u \\
v \\
\tilde{z} \\
\tilde{U}\end{array}$ & $\begin{array}{l}\overrightarrow{0} \\
\tilde{U}\end{array}$ & 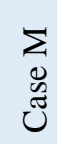 & 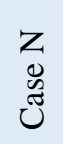 & \\
\hline 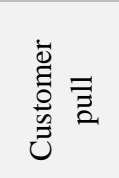 & & $\checkmark$ & $\checkmark$ & & $\checkmark$ & & & $\checkmark$ & & $\checkmark$ & & $\checkmark$ & $\checkmark$ & $\checkmark$ & $\begin{array}{l}\text { - Strong appetite from customer base to experiment with new innovation } \\
\text { - Initial request from key customers to purchase uptime rather that the asset } \\
\text { - Customer engagements in experimentation projects } \\
\text { - Level of maturity within the market about valuing outcome rather than the asset }\end{array}$ \\
\hline 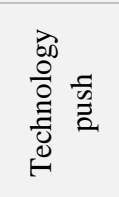 & $\checkmark$ & $\checkmark$ & & $\checkmark$ & $\checkmark$ & $\checkmark$ & & $\checkmark$ & $\checkmark$ & $\checkmark$ & $\checkmark$ & & & $\checkmark$ & $\begin{array}{l}\text { - The existence of the relevant technology to unlock the development of services-led offerings } \\
\text { - Maturity of the remote monitoring sensors in the market } \\
\text { - The realisation that new technologies could enable the company to do more } \\
\text { - The threat from digital technology start-ups in analysing data from the use of the asset }\end{array}$ \\
\hline 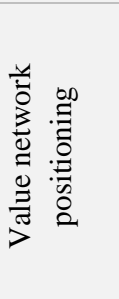 & & $\checkmark$ & $\checkmark$ & $\checkmark$ & & $\checkmark$ & $\checkmark$ & $\checkmark$ & $\checkmark$ & & $\checkmark$ & $\checkmark$ & & $\checkmark$ & $\begin{array}{l}\text { - Understanding of 'who the customers actually are' } \\
\text { - Awareness of the fact that the partner company within the value network may change as the service } \\
\text { proposition develops } \\
\text { - Restructuring the relationship with dealers to get control and direct access to customers } \\
\text { - Realisation of the existence of technology providers within the ecosystem, who could provide better, } \\
\text { cheaper, and more effective tools to enable the company's product to be smarter and provide a wide } \\
\text { range of offerings to their customers }\end{array}$ \\
\hline 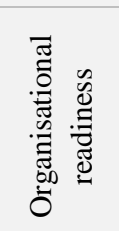 & $\checkmark$ & & $\checkmark$ & & $\checkmark$ & $\checkmark$ & $\checkmark$ & $\checkmark$ & & $\checkmark$ & $\checkmark$ & $\checkmark$ & & & $\begin{array}{l}\text { - Empathetic that advanced services journey could only start if you have a realisable product } \\
\text { - Experience of successful organisational transformation/acceptance of change } \\
\text { - Understanding the importance of internal buy-in to move towards servitization } \\
\text { - Organisational and strategic alignment across different business units } \\
\text { - Having the right service vision and mission for the entire organisation }\end{array}$ \\
\hline 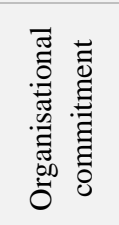 & $\checkmark$ & $\checkmark$ & & $\checkmark$ & $\checkmark$ & $\checkmark$ & $\checkmark$ & & $\checkmark$ & $\checkmark$ & & $\checkmark$ & & $\checkmark$ & $\begin{array}{l}\text { - Education of the senior management regarding the benefits of moving towards advanced services } \\
\text { - Identifying new opportunities among existing customers to support the transformation progress } \\
\text { - Engagement from the leadership in the development of advanced services offering early on } \\
\text { - Development of a shared service to manage the data across different segments } \\
\text { - Ability to learn from experimentation projects in the customer base }\end{array}$ \\
\hline
\end{tabular}

Table 5. Cross-case analysis of contextual factors 
The results show that each factor was active across several cases (ranging from 8 to 10 cases, out of 14), thus receiving significant replication. They also show that, in general, several factors are active in each individual case (at least three), suggesting that progress benefits from a conjunction of different forces. The exception is Case M, which as yet has only been subject to customer pull. Overall most factors appear to influence each stage of the process to a greater or lesser extent, and indeed may lead to particular pathways through each stage.

Customer pull refers to the external context factors about the market environment that affect the progression. As an illustration, the Service Director of Case C stated, 'We had to move towards output- or outcome-based contracts, because it was a direct request from two of our largest customers ... this did play in our favour later, as we didn't need to involve in engaging or persuading the customers for such offerings.'

Technology push refers to the external context factors about digital technologies that affect the progression. A good example took place in Case F. This firm became aware of technology that could record how its products (commercial trucks) were being used (e.g., driven by operators) and could transmit this data back to the operating company (logistics provider). Such data improved the operators ' visibility of drivers' actions, which subsequently led to a moderation of drivers' behaviour through the use of incentives and training. By bundling this with other services, Case $\mathrm{F}$ was then able to develop an advanced services contract based around payment for cargo moved rather than based on asset ownership. In this regard, the CFO of Case F stated: The technology change brought about a new realisation that we could do more. It was no longer enough for us to say this is the product, this is the component, these are the features and the benefits, and we had to start proving the performance. We then had to move towards taking care of the total cost of operation rather than cost of the asset.

Value network positioning refers to the external context factors about the value network structure that affect the progression. We found diverse examples in the cases. In Cases F and $\mathrm{N}$, the distributors were observed to restrict access to customers, field service facilities and improvements in performance to such an extent that they were acquired. Case I failed to progress beyond the Engagement stage because the distributor inhibited customer interaction, which the management of Case I failed to navigate. Somewhat similar situations occurred around the access to remote sensing technologies, as illustrated by Case F, which for some time wrestled with the decision to acquire a technology vendor in order to increase access to and control of information about truck fleets. All these cases provide evidence supporting the 
significant influence of positioning in the value network that delivers dependable access to both customers and suppliers.

Organisational readiness refers to the internal context factors about the organisation that affect whether or not the process starts. Particularly evident in the cases was the effect of the basic reliability and performance of the manufacturer's existing products. For example, Cases A, F, and $\mathrm{G}$ all indicated that their product platforms were entirely reliable, so that their interest in advanced services stemmed, in part, from product reliability and performance that were no longer differentiators. The CEO of Case F stated: 'Unless you manufacture a reliable asset, you will have no place in the advanced services space ... we build a reliable truck, so we can provide a platform of services.' In contrast, Case I was unable to reach an acceptable pace in its transformation journey because its products were not sufficiently reliable to form a platform for advanced services. The Service Director of the company said:

We cannot start adding services to a range of our engines yet, because we're still testing those engines and improving their efficiency. Unless we are convinced about the reliability of our product, I'm not convinced about getting any customer on board with advanced services.

Organisational commitment refers to the common internal factors that act across all stages and focuses on the key capabilities that enable or inhibit the progression. Organisational commitment has been widely acknowledged as a key success factor for any change efforts (Kotter and Cohen, 2002, Burnes, 2004). Case H, for instance, progressed relatively quickly through the Exploration and Engagement stages because it had the support of the management board. In contrast, Case $\mathrm{G}$ failed to move through the Engagement stage because it lacked internal support. The Chief Innovation Officer of Case A said of this issue:

One of the principal factors which has been influencing our transformation journey is the commitment from the people - not only the leadership and senior people but also those who are actively involved in the effort. Getting organisational buy-in is a real challenge; I had to go around lighting lots of little bush fires.

In Case A, organisational commitment to advanced services was enhanced when a principal competitor acquired a network of service providers in South America, which caused anxiety amongst the senior management of the case company. The reaction was to significantly increase investment in its own advanced services programme.

Analysis of the principal factors affecting progression through the transformation process provides a response to the second research question as follows: 
Proposition 2: In the transformation of a manufacturer to servitize and compete through advanced services, progress through the transformation process will be principally affected by (i) the extent of customer pull, (ii) the strength of technology push, (iii) the structure of the value network positioning, (iv) organisational readiness, and (v) organisational commitment.

\subsection{Nature of the organisational change process $(\mathrm{RQ3})$}

After having established the existence of stages and identified the contextual factors that significantly influenced progression, we addressed the nature of the transformation process. Specifically, we sought to determine whether the progression would be relatively linear or, instead, there would be reiterations and regression. Would there be consistency of decisions and actions within the stages? To find this out, we drew on the previously analysed patterns, as well as the detailed analysis of the dynamics of change within the cases, based on the rich qualitative data from the interviews.

Table 4 showed that all the firms seemed to follow the same sequence of four stages and there is no evidence that stages are skipped. Moreover, the individual case timelines (see Figure 2 for an example) showed that the events/actions associated with each stage were clustered around well-delimited time periods. Although in some cases there was some time overlap of events belonging to different stages, this overlap was short and confined to the transition period between stages. We also did not find evidence of actions/events belonging to the previous stage beyond the short transition period. Thus, at an aggregated level, the process appears to be structured and predominantly unidirectional.

However, the qualitative analysis of the dynamics of change also revealed that, within stages, there were sub-processes which were organic, unstructured and iterative. By looking at the transition periods, we also found evidence of tipping points between stages. These are triggered when the case for support is sufficiently strong, whether in terms of personal conviction or organisational permission, so that consent is achieved to move on to the following transformation stage. Companies would switch from Exploration to Engagement only when senior management became confident that a viable business opportunity existed; from Engagement to Expansion only when the potential of advanced services was accepted within the organisation; from Expansion to Exploitation only when significant value was demonstrated within the organisation. As illustrated by Cases G, I, L and M which did not move beyond the Engagement stage, not all companies had a sufficiently strong case to 
overcome the tipping points. Within the stages, multiple reiterations of decisions and actions took place until such tipping conditions prevail - that the transformation process 'tips' and moves on to the following stage. In the case studies, once the process had moved on to a new stage, it did not return to the preceding stage unless some form of relatively catastrophic change took place within the business. Case J illustrated this: the Service Director and Technical Director both described (independently) how they were experimenting with advanced service offerings (Engagement stage), but the circumstance of a senior board member's bereavement resulted in the loss of a major supporter. Subsequent staff changes ultimately resulted in the team being disbanded, the service strategy abandoned, and both the Service Director and Technical Director leaving the organisation.

The unstructured nature of the sub-processes was strongly influenced by the confluence of different contextual factors (see Table 5), which affected the detailed activities carried out by the firms. Case B, for example, was initially pulled by its customers into delivering advanced services. The strength of this pull was such that it affected the activities with which it engaged - for instance, it was not necessary to scan and analyse the market sector to identify relevant customers. Rather, the challenges centred more on developing the organisational conviction to take this opportunity, along with putting in place technologies to enable delivery of its advanced services. The situation for Case F, as another example, was different. By his nature, the company CEO was inquisitive about technology and how it might be exploited. He was introduced to one of the leading telematics providers, and the two companies collaborated closely to experiment on ways in which technology systems might enable Case F to develop and deliver advanced services. Case F experimented with, for example, having its own rental fleet to develop a proposition that could then be taken to market. Unlike Case B, it was necessary for Case F to scan, identify and engage customers. However, where Case B had to formally engage in joint ventures and acquisitions to enhance its technological capabilities and create its engine health management systems, Case F had implicitly moved through many of these decisions. Case A's initial driver was on of the senior personnel in the innovation team that were exploring ways to inspire growth, and came to recognise that business model innovation around advanced services could provide a possible route. Case A's interest was influenced by the growing attention to services by its key competitors. Consequently, it had to engage in a range of activities, from developing and experimenting with customer value propositions through to deciding on relationships with technology suppliers. However, Case A 
came to the process with a relatively higher level of organisational engagement and a more structured methodology for innovating the propositions.

This analysis of the nature of the organisational change process leads to the proposal:

Proposition 3: In the transformation of a manufacturer to servitize and compete through advanced services, the progression from one macro-stage to the next appears as structured and predominantly unidirectional, but within these are sub-processes which are characteristically organic, unstructured and iterative, and so the whole process can be characterised as a business growth model with multiple tipping points.

\section{DISCUSSION AND DEVELOPMENT OF THE MODEL}

This study has focused on the servitization of manufacturing firms and the organisational transformation such firms undergo in order to offer complex and sophisticated services at scale. We have revealed insights into (i) the rationalisation of this process into stages or steps, (ii) the contextual factors (what the situation was) which interplay on this process, and (iii) the change process (how change occurred) and the theory which describes this. We now discuss the formation of a theoretical model and contrast this research with other contemporary studies in the field.

\subsection{Formation of the servitization progression model}

Our findings and experiences from executing this study provide the basis for a theoretical model which explains how manufacturers progress through transformation processes when they servitize to compete through advanced services. Drawing together the propositions above enables the formation of such a model, and we refer to this as the servitization progression model (see Figure 3).

The servitization progression model explains how the servitization journey unfolds through four distinctive stages of organisational maturity, in accordance with five sets of internal and external forces. At a macro-level, progression from stage to stage appears linear and unidirectional; yet, within each stage, activities to progress servitization are organic, intuitive and repetitive. Progress from one macro-level stage to the next is punctuated by tipping points, which are only overcome once the activities of the preceding stage demonstrate sufficient value that the organisation consents to progression to the following stage. So significant are these 
tipping points that progression is not guaranteed, and under certain conditions the servitization journey may stall or even fail entirely. Overall, this process can be characterised as a business growth model.

The rate of progression is determined by five sets of forces. While organisational readiness seems to be present only in the first two stages, the other forces are present across the four stages. It is helpful to reflect how these forces typically interplay on the process. For instance, transformation only effectively begins if there is sufficient organisational readiness (i.e. reliable products, robust processes, etc.). Then the progression is significantly affected by the prevailing organisational commitment (i.e. management buy-in, resource availability, awareness of competitors, etc.). Working around these internal forces are the external forces of customer pull (i.e. customers requesting services, strong relationships, etc.), technology push (i.e. the availability of and access to digital technologies, etc.), and the value network positioning (i.e. relationships with distributors, dealers and vendors). These five forces interplay and collectively determine progress.

The servitization progression model explains the experience of practitioners within manufacturing firms typically in the following way. At inception, the process is triggered when one or more practitioners within the host organisation become aware of the general concepts of servitization and advanced services, and in accordance with the extent of their organisational commitment, they begin with Exploration and reflecting upon the concept. Then, if there is sufficient organisational readiness (and no immediate blocks apparent from other forces), they seek managerial consent to move on to the stage of Engagement. In Engagement, they search for evidence of customer demand (customer pull), and/or test the potential of technologies (technology push), and if suitable conditions prevail, they move to pilot and experiment with new advanced service offerings. If the outcomes of these are positive, these help to demonstrate the value of servitization to the organisation and progression takes place. However, this is inhibited if, for instance, the host organisation struggles to engage customers because they work through dealerships and distributors (value network). If the outcome of Exploration is positive, the organisation moves to Expansion. Pilots are translated into commercial offerings and there is a general increase in the scale and speed at which advanced services are innovated and implemented. Then, if expansion is successful, attention switches to Exploitation. In Exploitation, the organisation continues to develop new offerings and scale these, but also invests in initiatives to improve the reliability and efficiency of the delivery of services at scale. 
Finally, it is important to stress the scope of this study (see Section 2) as this bounds the validity of the model we propose. Primarily, this study has focused on manufacturing firms undergoing servitization (we have purposely excluded deservitization) and to describe the transformation process these firms have followed. This study has not considered the content (what was changed or what should be changed) of servitization, where servitization has been taken to be indicated through the sophistication of services offered (see Baines et al., 2009; 2017).

\subsection{Comparisons with contemporary servitization research}

The first finding from this study is that at an aggregated level the process of organisational change through servitization can be explained as four macro-stages: Exploration, Engagement, Expansion and Exploitation. This is largely consistent with the work of Lütjen et al. (2017) who identify the three steps of (i) service initiation, (ii) service anchoring and (iii) service extension, and these align with the Exploration, Engagement and Expansion stages. In the study described here, Exploitation is teased out as an additional stage, and this is attributed to our particular focus on servitization towards advanced services, and observing that some cases (e.g., Case B) have largely absorbed business improvement activities typical of this stage. There are more striking differences to the work of Martinez et al. (2017), who identify seven steps, along with limited commonality and considerable iterations. This difference is explainable by the different level of aggregation adopted in the study, and which is consistent with that suggested by Scott and Bruce (1987). In this way, our first finding emphasises the value of a higher level of aggregation (as per Lütjen et al. (2017)) for rationalising the servitization process as a manageable concept.

The second finding is that progression both between and within these macro-stages is significantly influenced by contextual factors. These can be grouped into five categories relating to customer pull, technology push, value network positioning, organisational readiness, and organisational commitment. It has been known for some time that contextual factors are central to shaping organisational transformation and progress towards servitization (Finne et al., 2013, Cusumano et al., 2015). Indeed, various works have looked at the barriers to servitization, particularly in terms of content (what have manufacturers sought to change?) (i.e., Baines and Shi, 2015). However, by establishing a holistic set of factors and categorising these as key influencers in the process of servitization, this paper provides the foundation to 
delve deeper into the factors in each category and their influence on detailed decisions within the process.

The third finding is that, while progression from one macro-stage to the next appears as structured and predominantly unidirectional, within these are sub-processes which are characteristically organic, unstructured and iterative. This reconciles the notions that: (i) servitization is a unidirectional and linear shift from products to product-service offerings (Turunen and Finne, 2014), and that (ii) the servitization process is neither logical nor structured (Martinez et al., 2017). In their work Martinez et al., describe how they observed that 'the chronological order of steps differs from journey to journey'. Likewise, Kowalkowski et al. (2017b:15) suggest evolutionary stages and 'tentative steps of trial and error'. Yet, the more general literature on organisational change and innovation demonstrates that process stages, iterations and key decision points can be approximately organised and ordered (see Section 2.3). Our study builds on this understanding and demonstrates that both sets of characteristics can be exhibited, depending on the level of aggregation at which the process is viewed (i.e. at a macro-level the process stages appear as a progression; yet the processes within these stages are unstructured and iterative). This is aligned with the business growth model developed by Scott and Bruce (1987) that comprises of multiple crises or tipping points, and helps to explain how the process of organisational change unfolds as a manufacturer undertakes the servitization journey. 


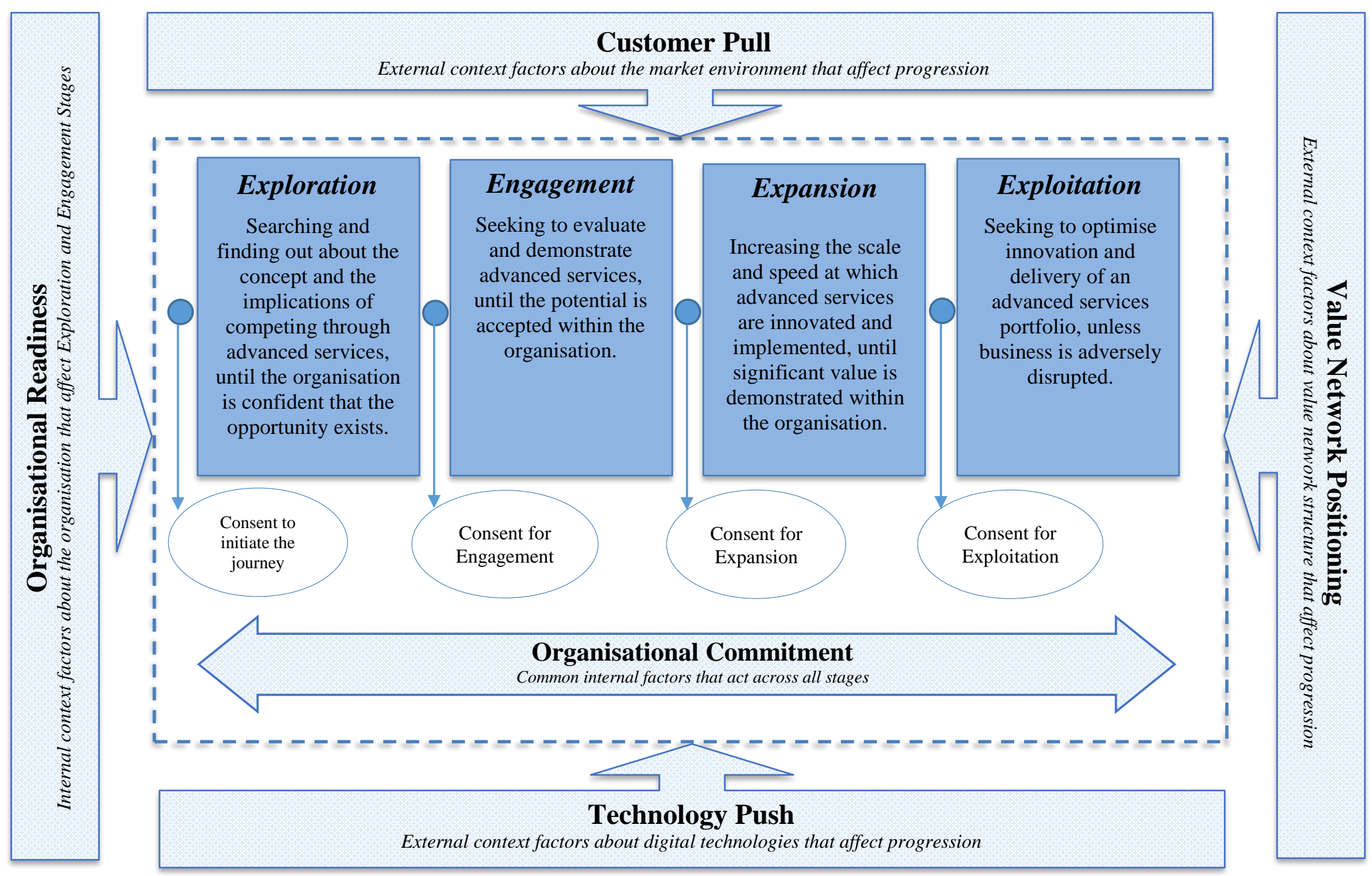

Figure 3. The servitization progression model 


\section{CONCLUSIONS}

The principal contribution of this study is a series of propositions, represented collectively as the servitization progression model, which describes the transformation process that takes place as a product-centric manufacturer servitizes to compete through advanced services. This model shows that the transformation process comprises four principal stages of organisational maturity, through which the manufacturer proceeds according to the pressures of five principal forces. This contribution has both theoretical and practical implications.

\subsection{Theoretical implications}

A recent review by Raddats et al. (2019) emphasises that there are still some fundamental aspects of servitization that warrant further research. Primarily, this paper answers the call for further research on the process and stages of organisational transformation towards servitization (Martinez et al., 2017), along with addressing the limited attention given to contextual factors (Baines et al., 2017). It establishes that: (i) the process of organisational change through servitization can be explained as the four macro-stages of Exploration, Engagement, Expansion and Exploitation, (ii) progression both between and within these macro-stages is significantly influenced by contextual factors, which can be grouped into five categories relating to markets, technology, organisational readiness, organisational commitment and the value network of the host business, and (iii) progression from one macrostage to the next appears as structured and predominantly unidirectional, punctuated by multiple tipping points; but within these stages are sub-processes that are characteristically organic, unstructured and iterative. The whole process can be characterised as a business growth model.

This study also (i) draws a distinction between the stages of the transformation process and the forces that could significantly influence progression, and (ii) focuses clinically on the process manufacturers have followed and avoiding intertwining a conversation about content. While our study largely builds on and develops insights into the transformation process, it also expands confidence because of the range and depth of organisations we have studied. Earlier studies of researchers such as Martinez et al. (2017) and Lütjen et al. (2017) have been crucial to forming new ideas around the structure of the transformation process, and our work provides 
a timely complement while building confidence through the depth and breadth of organisations studied.

\subsection{Practical implications}

Servitization can involve a raft of challenges for those executives from a production-centric background, especially for those faced with the task of evaluating and potentially implementing this concept within their organisation. This study has shown that a servitization programme will typically unfold through four stages of organisational change (exploration, engagement, expansion and exploitation) in accordance with a range of contextual factors, in which the factors and stages will interplay, and this will result in an iterative process with critical points where progress can stall.

Executives should find it particularly helpful to understand the characteristics of each stage along with those factors that are key to success. Figure 2 and Table 5 are helpful to illustrate typical activities in each stage and the associated contextual factors. On the basis of such data, we surmise that in the early exploration stage of a programme, executive sponsorship is likely to have the most influence on progress (i.e. Case $\mathrm{H}$ rapidly progressed because a board director was an advocate of the programme). Following this, engagement will focus on demonstrating the opportunity of servitization and the piloting of innovative customer value propositions. Most helpful at this stage is the use of in-depth (and ideally independent) customer analysis using empathising techniques and structured experimentation with new service offerings at carefully chosen customer sites (i.e. Case A applied these techniques and rapidly progressed through this stage, while Case $\mathrm{G}$ developed an offering largely based on assumptions of customer need and still fails to gain traction). The subsequent Expansion stage will be characterised by increasing tensions between the support and growth of the new service offering(s) and the established (production-centric) business model, and this is likely to result in turbulence around people, their priorities and structures (i.e. Case A experienced such upheaval that the executive responsible for the initial focus on services was retired from the organisation but, after a short period of tension, he was eventually replaced by an equally strong advocate of services). In the relatively mature stage of Exploitation, the focus will be characterised by initiatives to improve delivery efficiency while continuing to innovate advanced services (i.e. Case B is entirely focused on these priorities). 
The characteristics and priorities of an organisation at the earlier stage of maturity are very different to the later, and these distinctions are very important to recognise when executing popular management techniques such as benchmarking. The practitioner should also be mindful that the time taken to progress through these four stages can be significant and may take decades for a company embarking on a servitization programme to achieve the capabilities typical of the later stages of maturity.

\subsection{Limitations and opportunities for future work}

This research, similar to any other case study-based research, has certain limitations, which could provide opportunities for future work. These are summarised in the below three areas:

Development of a richer understanding of the process and content at each stage. During this study it was observed that particular techniques and specific decisions were commonly adopted. For instance, Cases A, H and K used a business model canvas (see Osterwalder et al., 2005) as an analytical tool during the Engagement stage, while Cases B, F and M put in place a dedicated business unit to support services during Expansion. Therefore, within the model established here, it would be valuable to understand the variety, popularity and sequencing of process and content within each stage. Also, it would be valuable to know the relationship between these and the forces impacting the progression - perhaps in the first instance by dealing with each stage separately and in-depth.

Investigate the linkages between context and process. A richer understanding of process and context would then allow an investigation into whether there are distinct selections and sequences of activities through the pathways. A likelihood exists that various pathways exist and organisations may switch pathways as people and contextual circumstances change.

Development of a prescriptive transformation roadmap. As mentioned, this descriptive study set out to lay the foundation for a more prescriptive process that practitioners can follow in order to servitize their businesses and compete through advanced services. Future research should explore links between different aspects of our progression model (e.g., the four macrostages, the five forces and their interplay) and servitization journey outcome measures, such as the rate of progression along the journey or the efficiency and effectiveness with which advanced services are provided. Rationalising this knowledge into a management aid is a logical next step, and yet caution will be required as the multitude of variables could easily result in a process that is overly complex and unworkable. As a recommendation for future 
work, an intermediate step would be to use this model, in the first instance, to audit existing servitization initiatives, and in doing so, to better understand how to apply this thinking in practice. 


\section{REFERENCES}

Ahamed, Z., Inohara, T. and Kamoshida, A. 2013. The servitization of manufacturing: An empirical case study of IBM Corporation. International Journal of Business Administration, 4, p18.

Alghisi, A. and Saccani, N. 2015. Internal and external alignment in the servitization journey Overcoming the challenges. Production Planning \& Control, 26, 1219-1232.

Armenakis, A. A. and Bedeian, A. G. 1999. Organizational change: A review of theory and research in the 1990s. Journal of Management, 25, 293-315.

Armenakis, A. A., Harris, S. G. and Feild, H. S. 2000. Making change permanent: A model for institutionalizing change interventions. Research in Organizational Change and Development, 12, 97-128.

Baines, T. and Lightfoot, H. 2013. Made to serve: How manufacturers can compete through servitization and product service systems, John Wiley \& Sons.

Baines, T. and Lightfoot, H. W. 2014. Servitization of the manufacturing firm: Exploring the operations practices and technologies that deliver advanced services. International Journal of Operations \& Production Management, 34, 2-35.

Baines, T. and Shi, V. G. 2015. A Delphi study to explore the adoption of servitization in UK companies. Production Planning \& Control, 1-17.

Baines, T., Ziaee Bigdeli, A., Bustinza, F., Guang Shi, V., Baldwin, J. and Ridgway, K. 2017. Servitization: Revisiting the state-of-the-art and research priorities. International Journal of Operations \& Production Management.37, 256-278.

Baines, T. S., Lightfoot, H. W., Benedettini, O. and Kay, J. M. 2009. The servitization of manufacturing: A review of literature and reflection on future challenges. Journal of Manufacturing Technology Management, 20, 547-567.

Bastl, M., Johnson, M., Lightfoot, H., \& Evans, S. (2012). Buyer-supplier relationships in a servitized environment: An examination with Cannon and Perreault's framework. International Journal of Operations \& Production Management, 32(6), 650-675.

Batista, L., Davis-Poynter, S., Ng, I. and Maull, R. 2017. Servitization through outcome-based contracts - A systems perspective from the defence industry. International Journal of Production Economics, 192, 133-143.

Benedettini, O., Neely, A. and Swink, M. 2015. Why do servitized firms fail? A risk-based explanation. International Journal of Operations \& Production Management, 35, 946-979.

Bikfalvi, A., Lay, G., Maloca, S. and Waser, B. R. 2013. Servitization and networking: Large-scale survey findings on product-related services. Service Business, 7, 61-82.

Brax, S. A. and Visintin, F. 2017. Meta-model of servitization: The integrative profiling approach. Industrial Marketing Management, 60, 17-32.

Burnes, B. 2004. Managing change: A strategic approach to organisational dynamics, Pearson Education.

Burton, J., Story, V. M., Raddats, C. and Zolkiewski, J. 2017. Overcoming the challenges that hinder new service development by manufacturers with diverse services strategies. International Journal of Production Economics, 1-11.

Bustinza, O. F., Bigdeli, A. Z., Baines, T. and Elliot, C. 2015. Servitization and competitive advantage: The importance of organizational structure and value chain position. ResearchTechnology Management, 58, 53-60.

Bustinza, O. F., Parry, G. C. and Vendrell-Herrero, F. 2013. Supply and demand chain management: The effect of adding services to product offerings. Supply Chain Management - An International Journal, 18, 618-629.

Chakkol, M., Johnson, M., Raja, J. and Raffoni, A. 2014. From goods to solutions: How does the content of an offering affect network configuration? International Journal of Physical Distribution and Logistics Management, 44, 132-154.

Cusumano, M. A., Kahl, S. J. and Suarez, F. F. 2015. Services, industry evolution, and the competitive strategies of product firms. Strategic Management Journal, 36, 559-575.

Dmitrijeva, J., Ziaee Bigdeli, A., Schroeder, A. and Baines, T. Contextualising servitization - The shaping of the organisational transformation. EurOMA 2018 Budapest. 
Durugbo, C. 2014. Strategic framework for industrial product-service co-design: Findings from the microsystems industry. International Journal of Production Research, 52, 2881-2900.

Eggert, A., Hogreve, J., Ulaga, W. and Muenkhoff, E. 2014. Revenue and profit implications of industrial service strategies. Journal of Service Research, 17, 23-39.

Eisenhardt, K. M. 1989. Building theories from case study research. Academy of Management Review, $14,532-550$.

Eloranta, V. and Turunen, T. 2016. Platforms in service-driven manufacturing: Leveraging complexity by connecting, sharing, and integrating. Industrial Marketing Management, 55, 178-186.

Finne, M., Brax, S. and Holmström, J. 2013. Reversed servitization paths: A case analysis of two manufacturers. Service Business, 7, 513-537.

Finne, M., Turunen, T. and Eloranta, V. 2015. Striving for network power: The perspective of solution integrators and suppliers. Journal of Purchasing and Supply Management, 21, 9-24.

Gaiardelli, P., Resta, B., Martinez, V., Pinto, R. and Albores, P. 2014. A classification model for product-service offerings. Journal of Cleaner Production, 66, 507-519.

Galpin, T. J. 1996. The human side of change: A practical guide to organization redesign, Jossey-Bass Publishers.

Gebauer, H. 2008. Identifying service strategies in product manufacturing companies by exploring environment-strategy configurations. Industrial Marketing Management, 37, 278-291.

Gebauer, H. and Friedli, T. 2005. Behavioral implications of the transition process from products to services. Journal of Business \& Industrial Marketing, 20, 70-78.

Gebauer, H., Gustafsson, A. and Witell, L. 2011. Competitive advantage through service differentiation by manufacturing companies. Journal of Business Research, 64, 1270-1280.

Hargrave, T. J. and Van De Ven, A. H. 2006. A collective action model of institutional innovation. Academy of Management Review, 31, 864-888.

Hatch, M. J. 2012. Organization theory: Modern, symbolic and postmodern perspectives, Oxford University Press.

Holmström, J. and Partanen, J. 2014. Digital manufacturing-driven transformations of service supply chains for complex products. Supply Chain Management: An International Journal, 19, 421-430.

Jick, T. D. 1979. Mixing qualitative and quantitative methods: Triangulation in action. Administrative Science Quarterly, 24, 602-611.

Johnstone, S., Dainty, A. and Wilkinson, A. 2009. Integrating products and services through life: An aerospace experience. International Journal of Operations \& Production Management, 29, 520-538.

Judson, A. S. 1991. Changing behavior in organizations: Minimizing resistance to change, B. Blackwell.

Kamp, B. and Parry, G. 2017. Servitization and advanced business services as levers for competitiveness. Industrial Marketing Management, 60, 11-16.

Kelly, D. and Amburgey, T. L. 1991. Organizational inertia and momentum: A dynamic model of strategic change. Academy of Management Journal, 34, 591-612.

Kindström, D. and Kowalkowski, C. 2014. Service innovation in product-centric firms: A multidimensional business model perspective. Journal of Business and Industrial Marketing, 29, 96111.

Kohtamäki, M., Partanen, J. and Möller, K. 2013a. Making a profit with R\&D services - The critical role of relational capital. Industrial Marketing Management, 42, 71-81.

Kohtamäki, M., Partanen, J., Parida, V. and Wincent, J. 2013b. The non-linear relationship between industrial service offering and sales growth: The moderating role of network capabilities. Industrial Marketing Management, 42, 1374-1385.

Kotter, J. P. 1995. Leading change: Why transformation efforts fail. Harvard Business Review, 73, 5967.

Kotter, J. P. and Cohen, D. S. 2002. The heart of change: Real-life stories of how people change their organizations, Harvard Business Press.

Kowalkowski, C., Brehmer, P. O. and Kindstrom, D. 2009. Managing industrial service offerings: Requirements on content and processes. International Journal of Services Technology and Management, 11, 42-63.

Kowalkowski, C., Gebauer, H., Kamp, B. and Parry, G. 2017a. Servitization and deservitization: Overview, concepts, and definitions. Industrial Marketing Management, 60, 4-10. 
Kowalkowski, C., Kindström, D., Alejandro, T. B., Brege, S. \& Biggemann, S. (2012). "Service infusion as agile incrementalism in action". Journal of Business Research, 65, 765-772.

Kowalkowski, C., Gebauer, H. and Oliva, R. 2017b. Service growth in product firms: Past, present, and future. Industrial Marketing Management, 60, 82-88.

Langley, A., Smallman, C., Tsoukas, H. and Van De Ven, A. H. 2013. Process studies of change in organization and management: Unveiling temporality, activity, and flow. Academy of Management Journal, 56, 1-13.

Lee, J., Kao, H. A. and Yang, S. 2014. Service innovation and Smart Analytics for Industry 4.0 and Big Data environment. Procedia CIRP, 16, 3-8.

Lewin, K. 1947. Frontiers in group dynamics II. Channels of group life; social planning and action research. Human Relations, 1, 143-153.

Lienert, A. 2015. Change of culture or culture of change? Introducing a path-agency-culture (PAC) framework to servitization research. Procedia CIRP, 30, 353-358.

Lightfoot, H. W., Baines, T. and Smart, P. 2011. Examining the information and communication technologies enabling servitized manufacture. Proceedings of the Institution of Mechanical Engineers, Part B: Journal of Engineering Manufacture, 225, 1964-1968.

Lindberg, N. and Nordin, F. 2008. From products to services and back again: Towards a new service procurement logic. Industrial Marketing Management, 37, 292-300.

Luecke, R. 2003. Managing change and transition, Harvard Business Press.

Lütjen, H., Tietze, F. and Schultz, C. 2017. Service transitions of product-centric firms: An explorative study of service transition stages and barriers in Germany's energy market. International Journal of Production Economics, 192, 106-119.

Martinez, V., Bastl, M., Kingston, J. and Evans, S. 2010. Challenges in transforming manufacturing organisations into product-service providers. Journal of Manufacturing Technology Management, 21, 449-469.

Martinez, V., Neely, A., Velu, C., Leinster-Evans, S. and Bisessar, D. 2017. Exploring the journey to services. International Journal of Production Economics, 192, 66-80.

Mathieu, V. 2001. Product services: From a service supporting the product to a service supporting the client. Journal of Business and Industrial Marketing, 16, 39-53.

Miles, M. B. and Huberman, A. M. 1994. Qualitative data analysis: An expanded sourcebook, Sage.

Mont, O. 2004. Institutionalisation of sustainable consumption patterns based on shared use. Ecological Economics, 50, 135-153.

Neely, A. 2008. Exploring the financial consequences of the servitization of manufacturing. Operations Management Research, 1, 103-118.

Nordin, F., Lindahl, I. and Brege, S. 2013. The Applicability of Integrated Solutions Offerings: Differential Effects of Product Complexity. Journal of Relationship Marketing, 12, 59-78.

Oliva, R. and Kallenberg, R. 2003. Managing the transition from products to services. International Journal of Service Industry Management, 14, 160-172.

Opresnik, D. and Taisch, M. 2015. The value of Big Data in servitization. International Journal of Production Economics, 165, 174-184.

Osterwalder, A., Pigneur, Y. and Tucci, C. L. 2005. Clarifying business models: Origins, present, and future of the concept. Communications of the Association for Information Systems, 16, 1-25.

Paiola, M., Saccani, N., Perona, M. and Gebauer, H. 2013. Moving from products to solutions: Strategic approaches for developing capabilities. European Management Journal, 31, 390-409.

Parida, V., Sjödin, D. R., Wincent, J. and Kohtamäki, M. 2014. Mastering the transition to productservice provision: Insights into business models, learning activities, and capabilities. Research Technology Management, 57, 44-52.

Pettigrew, A. M. 1988. The management of strategic change, B. Blackwell.

Pye, A. and Pettigrew, A. 2005. Studying board context, process and dynamics: Some challenges for the future. British Journal of Management, 16, S27-S38.

Raddats, C. and Burton, J. 2011. Strategy and structure configurations for services within productcentric businesses. Journal of Service Management, 22, 522-539.

Raddats, C. and Kowalkowski, C. 2014. A reconceptualization of manufacturers' service strategies. Journal of Business-to-business Marketing, 21, 19-34. 
Raddats, C., Kowalkowski, C., Benedettini, O., Burton, J. and Gebauer, H., 2019. Servitization: A contemporary thematic review of four major research streams. Industrial Marketing Management.

Scott, M. and Bruce, R. 1987. Five stages of growth in small business. Long Range Planning, 20, 4552.

Selviaridis, K. and Norrman, A. 2014. Performance-based contracting in service supply chains: A service provider risk perspective. Supply Chain Management, 19, 153-172.

Spring, M. and Araujo, L. 2013. Beyond the service factory: Service innovation in manufacturing supply networks. Industrial Marketing Management, 42, 59-70.

Strauss, A. and Corbin, J., 1998. Basics of qualitative research: Procedures and techniques for developing grounded theory. Sage publications.

Story, V. M., Raddats, C., Burton, J., Zolkiewski, J. and Baines, T. 2017. Capabilities for advanced services: A multi-actor perspective. Industrial Marketing Management, 60, 54-68.

Tukker, A. 2004. Eight types of product-service system: Eight ways to sustainability? Experiences from SusProNet. Business Strategy and the Environment, 13, 246-260.

Turunen, T. and Finne, M. 2014. The organisational environment's impact on the servitization of manufacturers. European Management Journal.

Tushman, M. L. and Anderson, P. 1986. Technological discontinuities and organizational environments. Administrative Science Quarterly, 439-465.

Ulaga, W. and Reinartz, W. J. 2011. Hybrid offerings: How manufacturing firms combine goods and services successfully. Journal of Marketing, 75, 5-23.

Valtakoski, A. 2017. Explaining servitization failure and deservitization: A knowledge-based perspective. Industrial Marketing Management, 60, 138-150.

Vandermerwe, S. and Rada, J. 1988. Servitization of business: Adding value by adding services. European Management Journal, 6, 314-324.

Vendrell-Herrero, F., Parry, G., Bustinza, O. F. and O'Regan, N. 2014. Servitization as a driver for organizational change. Strategic Change, 23, 279-285.

Whipp, R., Rosenfeld, R. and Pettigrew, A. 1989. Managing strategic change in a mature business. Long Range Planning, 22, 92-99.

Wilkinson, A., Dainty, A., Neely, A., Brax, S. A., \& Jonsson, K. (2009). Developing integrated solution offerings for remote diagnostics. International Journal of Operations \& Production Management. 29. 539-560.

Wilkinson, A., Dainty, A., Neely, A. and Schmenner, R. (2009), "Manufacturing, service, and their integration: some history and theory", International Journal of Operations \& Production Management, Vol. 29 No. 5, pp. 431-443.

Windahl, C. and Lakemond, N. 2010. Integrated solutions from a service-centered perspective: Applicability and limitations in the capital goods industry. Industrial Marketing Management, 39, 1278-1290.

Yin, R. K. 2003. Case study research design and methods. Applied Social Research Methods Series, 5.

Ziaee Bigdeli, A., Bustinza, O.F., Vendrell-Herrero, F. and Baines, T., 2018. Network positioning and risk perception in servitization: evidence from the UK road transport industry. International Journal of Production Research, 56, 2169-2183. 